\title{
Arguing the Just War in Islam
}

Massachusetts: Harvard University Press, 2009

\author{
By John Kelsay
}

Reviewed by

Ridwan Rosdiawan

(Universitas Islam Negeri Jakarta)

One of the magnitude effect of the horrific 9/11 terrorist attacks on the United States and the subsequent war against terror campaign is a political rhetoric that divides the international world into two rigid poles," the evil terrorist" in one side and the "righteous, just enlightened victim" in the other. The United States administration has succeeded in placing itself as the protagonist side and its rally for retaliatory war campaign has not only gained international support but also affirmed its position as the leader of the 'the key-holder of freedom, liberty and humanity', who waged war against the barbaric evil terrorists. By calling 'either with us or against us', the US leaves no room for the rests of the world to be in 'grey' area. Those who are not in favor will be considered as enemy and therefore deserve to be punished.

All words in quotations above, which are taken from several official speeches spoken by President George W. Bush, are certainly functional. They must be articulated in a way that produces the useful meaning in differentiating the good 'us' against the evil 'them'. This meaning, in turn, will be the ideological basis that justify the good 'us' to take any necessary action to punish the bad them even in the worst form. This is the simplest way to comprehend why almost all states in the world appear to be in one voice supporting the US action in launching war campaign and attacking those who considered as terrorist.

The subsequent problematic consequences then emerge. The targets of the US war against terror campaigns are heavily imbued with symbols affiliated to a large part of world's community. Osama bin Laden, the Taliban and Saddam Hussein of Iraq are often perceived as the representative symbols of Islam since they always speak on behalf of defending Islam and Muslim. They argue that each of their political and mostly violent actions are divinely inspired and waged under the spirit of 'Jihad'. This reasoning initially raises some questions to the world's audiences particularly those who unfamiliar with Islamic teachings: How can the religion which means peace and attracts more than 1.3 billion people of the world tolerate violence? How can noble teachings of 
the religion inspire its adherents to murder innocent civilians? Why is there also a large portion of Muslim community who condemn the violent actions perpetrated by their fellow Muslims?

It is in the light of this issue that John Kelsay, a Research Professor of Religious Ethics at Florida State University, wrote one of his monumental book s entitled Arguing the Just War in Islam. Raising objection to the notion that the former attacks on US interests abroad and on the civilian targets homeland has nothing to do with Islam, Kelsay argued that the attacks are better construed as religious. "Those who wish to argue that Islam has nothing to do with the attacks of 9/11 or with the tactics of Iraqi "insurgents"....., Kelsay continued, “... will find no comfort here. The facts are plain. Osama bin Laden, Ayman al-Zawahiri, and other militants lay claim to some of the central practices and themes of Islamic tradition." (p.3) In the easier terms, Kelsay pointed out that those carrying out the attacks were and are Muslims. They cite Islamic sources and speak in Islamic terms.

Even though Kelsay clearly stressed the point of his logic departure, the linkage between Islam and violence is obviously not the main concern of his writing. Arguing the Islamic just war does not mean that Kelsay criticized how Muslims formulate the concepts, definitions and practices of Jihad. Rather, by this book, he tried to make an introductory remark by approaching the nature of Islamic tradition surrounding the issue. "Muslims today are involved in a serious argument about political ethics...", he said, “... [and] This argument is framed in terms of practices that are central to Islamic tradition.” (p. 4)

Muslims, to Kelsay, believe that humans being must live within divinely ordered limits and not all ways of ordering life are morally equivalent. Islam, thus, is a living tradition, in which men and women attempt to forge links between the wisdom of previous generations and the challenges posed by contemporary life, in hopes of acting in ways consistent with the guidance of God. The divine guidance embodied a concept of governing law, the Sharia, and its reasoning is one of the modes, if not the primary mode, in which contemporary Muslims make this attempt.

It is within this framework that Kelsay constructed his book discussion. The focus was put on the debate over armed force and political ethics inspired by the arguments of militant activists while the description on the practice of Sharia reasoning among contemporary Muslims was employed as an explanatory background. According to Kelsay, militant activists such as Bin Laden and his comrades justified their violent actions under the basis of complex interpretation of Sharia. They applied the strategic logic of reasoning that is borrowed from the tradition of their predecessors within the last two 
centuries. The situation is also quite similar to those who are regarded to be 'moderate' Muslims. Their condemnation to the conducts of their fellow militants was mainly based on the consideration of Sharia reasoning. The form of argument associated with Shari'a reasoning involves appeals to tradition. Kelsay explained, "Arguments are evaluated as better or worse, persuasive or not, in terms of the ways in which advocates of various positions make use of historical precedents."

He continued that differences between the political ideas advanced by militants and those advanced by other Muslims are not settled by way of appeals to broad or abstract principles like equality or respect for the autonomy of persons. Rather, those engaged in Shari'a reasoning cite texts, which are interpreted in connection with particular instances in the story Muslims tell about the beginnings and subsequent development of their tradition. Respect for tradition manifests itself in the ways in which people interpret, for example, the Prophet Muhammad's orders to Muslim soldiers or the military response of Abu Bakr, the first Khalifa, or leader, of the Muslims following the death of the Prophet in 632, to the "turning" or "apostasy" of certain Arab tribes.

To comprehensively understand how contemporary Muslims articulate the notions of the just war requires a good deal of knowledge about the ways Muslims tell the story of the emergence and development of their community. Kelsay elaborated the topics by firstly emphasizing the focus on answering the question "What is Islam?" and providing the answer in forms of historical and religious context in which Muslim arguments about war and political ethics make sense. He, then, went on discussing how Muslims came to a consensus regarding the range of sources appropriate for those engaged in Sharia reasoning, as well as the rules governing the interpretation of approved texts. In this section, Kelsay put much emphasis on describing the growth of a class of specialists, al-'Ulama'. He also outlined the most important political and military judgments advanced by members of this class between 750 and 1400 C.E. The contemporary Muslims' effort, he argued, in measuring the rights and wrongs of specific proposals regarding the political uses of military force borrows much of its concept to a set of standard references or "consensual precedents" established in that period. It was in this period Muslim political power was at its height and that most of the ahkam al-jihad, or judgments pertaining to armed struggle emanated.

The sub-ordinate position of the world of Islam under the domination of western colonization has forced Muslims to develop some sets of new codes that govern their conducts. The shifting power of Muslim in global arena following the decline of the Ottoman empires provided chances to Muslim 
community to produce new ways of arguments. Some pursued to modernize their thought by fully adopting advanced western cultures. There were also Muslims who try to produce arguments based on reasoning by reconciling the modern thought and the Islamic teachings. At the other end, militant Muslims produced their arguments as an antidote to the presence of western cultures in their milieu. Kelsay highlighted the ways in which today's militants may be understood as the most recent exponents of an argument advanced by numerous Muslims over the last two centuries. The concept of just war in the mind of contemporary Muslim militants, according to him, is in fact a reproductive process by way of an attempt to "stretch" the consensual precedents associated with the pre-modern ahkam al-jihad to the new situations created by European colonialism and, more recently, by the geopolitical predominance of the United States. Kelsay also demonstrated that the controversy over militant justifications of armed resistance indicates a crisis of legitimacy in Muslim thought. Arguments on all sides in this controversy reflect the lack of Muslim consensus regarding the identification of legitimate or right authority in affairs of state. They may also be interpreted as reflecting a crisis in the practice of Shari'a reasoning itself.

Kelsay concluded that the fate of Muslim democracy may well be connected with the conduct of the war on terror. The conflict between advocates of democracy and Islamic militants is a defining moment for humanity. For Osama bin Laden, the conflict has similar import. In the current political setting, the give-and-take between Muslims and non-Muslims regarding the just war constitutes a critical aspect of democratic practice. Even as the war on terror will have an impact on the cause of Muslim democrats, so the fate of Muslim democrats is going to have an impact on the political future in the United States, the European Union, and around the world.

Overall, Kelsay's Arguing the Just War in Islam is worth of reading. Its excellent detailed explanations help readers new to information about Islam in grasping the word of Jihad and understanding how the word interpreted and debated within the Muslim world along the course. Despite the fact that Kelsay employed secondary resources (references in forms of translation) when discussing the sensitive case of Islamic teachings, the book can be the entering point to the deeper study of comprehensive understanding on Islam and Muslim. 